\title{
Effect of Mollusc Eating on Human Bone Strontium Levels
}

\author{
Margaret J. Schoeninger ${ }^{a b}$ and Christopher S. Peebles ${ }^{c}$
}

\begin{abstract}
Empirical aspects of the movement of strontium through the food chain suggest that the level of bone strontium can be used as an indicator of the percentage of meat in human diet. In general, skeletal remains from agricultural peoples are expected to have high bone strontium levels relative to hunter-gatherers from the same geographical region because plants contain relatively higher amounts of strontium when compared with animal products. The results of the study described in this paper, however, indicate that the inclusion of molluscs as a component of the diet may produce the opposite of the expected strontium values. Burials from an Archaic (c. $2500 \mathrm{BC}$ ) hunting-gathering population excavated from $\mathrm{Lu}^{\circ} 25$, an archaeological site in northern Alabama, USA, exhibit a mean bone strontium level ( $\bar{X}=465$ p.p.m. atomic absorption; $\bar{X}=475$ p.p.m. neutron activation) that is higher than the mean level from an agricultural Mississippian (c. AD 1400) population ( $\bar{X}=295$ p.p.m. atomic absorption; $\bar{X}=255$ neutron activation) that was buried at the same site. The samples were analysed by two techniques (atomic absorption spectrometry and neutron activation analysis) and the results compared favourably; therefore, the results can be accepted as valid rather than being due to technique error. We propose that the ingestion of molluscs, whose meat is known to contain large amounts of strontium, has produced this reversal from expected results.
\end{abstract}

Keywords: DIETARY RECONSTRUCTION, BONE STRONTIUM LEVELS, MOLLUSC EATING, AMERINDIAN, ARCHAIC, MISSISSIPPIAN, ATOMIC ABSORPTION SPECTROMETRY, NEUTRON ACTIVATION ANALYSIS.

\section{Introduction}

The amount of strontium in human bone can be a sensitive indicator of the relative composition of the diet of prehistoric human populations (Brown, 1973; Schoeninger, $1979 a, b)$. There are, however, certain aspects of the fractionation of strontium through the food chain which must be considered before the level of strontium in human bone

\footnotetext{
"Department of Anthropology and Museum of Anthropology, The University of Michigan, Ann Arbor, Michigan 48109, U.S.A.

${ }^{b}$ Present addresses: Department of Cell Biology and Anatomy, The Johns Hopkins University School of Medicine, Baltimore, Maryland 21205 and The Department of Farth and Space Science, The University of California at Los Angeles, Los Angeles, California 90024, U.S.A.

'Present addresses: Institute Voor Prac- en Protohistorie, Universieit Van Amsterdam, The Netherlands and The Department of Anthropology, The University of Alabama, Tuscaloosa, Alabama, U.S.A.
} 
can be used as a specific indicator either of dietary composition or of a population's position in the food chain. The assumption that agriculturalists can be separated from hunter-gatherers by the relatively greater amounts of strontium in the former's skeletal material may be overly simplistic. An example is provided through measurement of the level of stable strontium in the bones of a hunter-gatherer population and an agricultural population that, although separated in time by 3000 or more years, lived and then buried their dead in the same archaeological site. Because the diet of the huntergatherers included molluscs, whose flesh contains relatively high levels of strontium (Schroeder et al., 1972), we expected the levels of bone strontium within this population to be higher than would be predicted based on their position in the food chain. As expected, the level of strontium in their bones was significantly higher ( 1.5 to 1.8 times) than that of the agriculturalists, a marked reversal of the levels predicted by the most simplistic food chain model.

The argument for the use of strontium as an indicator of diet begins with environmental strontium (Toots \& Voorhies, 1965). Although the sedimentary cycle of strontium appears to be stable, the distribution of strontium throughout the physical environment is uneven (Odum, 1951; Odum, 1971). The amount of strontium in living organisms is determined by the amount of strontium present in the soil and by biotic factors. In general, the ratio of strontium to calcium in plants is the same as that in the soil, although some plants discriminate against strontium and others concentrate it (Bowen \& Dymond, 1955; Vose \& Koontz, 1955; Comar et al., 1957). Because the distribution of strontium is uneven throughout the physical environment, the same species of plant may contain different amounts of strontium when grown on different soils.

The level of strontium in the bones of terrestrial vertebrates reflects the level of strontium in their diet minus the large and constant percentage that is eliminated through excretion, lactation or placental transfer. Unlike calcium, strontium does not appear to be under homeostatic control in vertebrates; a constant percentage of dietary strontium crosses the gut and enters the blood stream (Comar \& Wasserman, 1964; Berg, 1972). There seems to be no initial discrimination against strontium by bone mineral (hydroxyapatite) and no differential removal of strontium relative to calcium from mature bone mineral (Neuman et al., 1963; McLean \& Urist, 1968; Marchall et al., 1973; Reeve \& Hesp, 1976); therefore, the amount of strontium in bone is a reflection of the amount of strontium available in the blood (Underwood, 1977). As a result, the amount of strontium in the bones of terrestrial vertebrates is ultimately determined by the level of strontium in the diet. Since $99 \%$ of the strontium stored in the body is sequestered in bone mineral while the soft tissues contain very low amounts of strontium (Schroeder et al., 1972), a diet composed largely of meat should contain a relatively low level of strontium. As a consequence, herbivores will have a larger amount of strontium in their diet and ultimately in their bone mineral than will carnivores who subsist on animal flesh which contains very little strontium.

The above generalization is true only when both the herbivores and carnivores are located within the same geographical region and are part of the same biotic community. Because of the uneven distribution of strontium throughout the physical environment, the bone strontium levels of skeletal populations from different geographical regions cannot be directly compared. In addition, comparison of bone strontium levels in a modern skeletal series with those of a prehistoric series may not be meaningful for two reasons: (1) the geographic location in which the two populations lived may be vastly different, and (2) the modern transportation industry provides a diet which comes from the four corners of the continent if not the world. An additional exception to these generalizations about plants and animals is provided by aquatic molluscs. Ophel (1963), who traced ${ }^{90} \mathrm{Sr}$ in the community metabolism of a lake, demonstrated that this isotope 
was concentrated 730 -fold in the meat of freshwater molluscs (see also Kulebakina, 1975).

Anthropologists have used the level of strontium in bone either as an indicator of a population's dependence on domesticated grasses or to show differential consumption of vegetable foods and animal protein between social strata within agricultural societies (Brown, 1973; Gilbert, 1975; Schoeninger, 1979a, b). These analyses depended on the assumption that, in general, agricultural populations would have ingested and retained significantly higher amounts of strontium from their plant diet than would omnivorous hunter-gatherers, who, in turn would have incorporated greater amounts of dietary strontium than would hunters almost wholly dependent on animal products (e.g. Netsilik and Copper Eskimo; Balikci, 1968; Damas, 1972). We recognize the problems in assuming that hunter-gatherers necessarily must ingest greater amounts of animal products than must agriculturalists. However, given the amount of animal bone deposited in Archaic period sites, the assumption probably is sound for this portion of North America. Such archaeological evidence, used in conjunction with trace element analysis, is the best indicator of prehistoric diets since, as discussed in Lee \& DeVore (1968, pp. 92-94), the diet of extant hunter-gatherers distributed in marginal areas may not be indicative of the diet of prehistoric hunter-gatherers living in areas where game was abundant. On the other hand, even if the general assumption is accepted, the linear carnivore to herbivore scale may not adequately classify the diet of the population if molluscs had been incorporated in the diet.

In order to investigate the effect of molluses in the diet on the level of strontium in bone mineral, this element was measured in a small sample of skeletal remains from two populations, one of which regularly consumed molluscs, the other of which did not. To minimize unwanted environmental variation in the sources of strontium, both samples were drawn from burials interred in the same archaeological site. This site, $\mathrm{Lu}^{\circ} 25$, was a large shell mound situated on the north end of Seven Mile Island, Lauderdale County, Alabama (Webb \& DeJarnette, 1942, 1948). The prehistoric utilization of this site spanned a period from before $3000 \mathrm{BC}$ to after AD 1400. There were, however, two major occupations within this time span: one in the Late Archaic period (c. 2500 BC); the other in the Mississippian period (c. AD 1400). Almost all of the 1025 burials excavated from this site prior to its inundation by the closing of the Pickwick Dam can be assigned to one or the other of these periods. Ribs were taken from three late Archaic burials and three Mississippian burials. Only burials with clear archaeological context

Table 1. Measures and sample statistics for Sr in bones of Archaic and Mississippian burials at $\mathrm{Lu}^{\circ} 25$

\begin{tabular}{|c|c|c|c|c|c|}
\hline & \multirow[b]{2}{*}{$\begin{array}{c}\text { Burial No. } \\
\text { (Snow) }\end{array}$} & \multirow[b]{2}{*}{ Sex } & \multirow[b]{2}{*}{ Age } & \multicolumn{2}{|c|}{ Strontium (p.p.m.) } \\
\hline & & & & $\begin{array}{l}\text { Atomic } \\
\text { absorption }\end{array}$ & $\begin{array}{l}\text { Neutron } \\
\text { activation }\end{array}$ \\
\hline Mississippian & $\begin{array}{l}178 \\
401 \\
609\end{array}$ & $\begin{array}{l}M \\
F \\
M\end{array}$ & $\begin{array}{l}56-75 \\
20-22 \\
22-26\end{array}$ & $\begin{array}{l}324 \\
297 \\
263\end{array}$ & $\begin{array}{l}236 \\
277 \\
250\end{array}$ \\
\hline Archaic & $\begin{array}{l}574 \\
530 \\
086\end{array}$ & $\begin{array}{l}\mathbf{F} \\
\mathbf{M} \\
\mathbf{M}\end{array}$ & $\begin{array}{l}25-30 \\
45-50 \\
21-35\end{array}$ & $\begin{array}{r}\bar{X}=295 \\
s=31 \\
462 \\
478 \\
454\end{array}$ & $\begin{array}{r}\bar{X}=255 \\
s=21 \\
415 \\
471 \\
538\end{array}$ \\
\hline & & & & $\begin{array}{r}\bar{X}=465 \\
s=12\end{array}$ & $\begin{array}{r}\bar{X}=475 \\
s=61\end{array}$ \\
\hline
\end{tabular}


were considered, and the individuals were matched as closely as possible for age and sex (Table 1). In this way differences in diet became the major source of variation between the two samples.

Late Archaic populations of the Middle Tennessee Valley, like other "Riverine Archaic" groups in the eastern United States, were predominantly gatherers and hunters of wild foods, although horticulture did play a minor role in their subsistence pursuits. The majority of their diet came from wild plants, including small seeds, nuts, and animals including deer, small mammals, turkey, migratory waterfowl, fish, turtle and molluscs (Asch, Ford \& Asch, 1972; Ford, 1974, 1977; Marquardt \& Watson n.d.; Dye, 1977). Although molluses were a minor component in the diet as a whole, they were a seasonally important source of food.

In the Middle Tennessee Valley the Late Archaic populations exploited 56 species of shallow water molluscs and 22 species of fresh water snails (Morrison, 1942). If, as has been estimated, $25 \%$ of the shell mounds were composed of shell, then $\mathrm{Lu}^{\circ} 25$ contains approximately $10,000 \mathrm{~m}^{3}$ of snail and molluscan remains. Despite this mass of shell, deer and other animals contributed far more protein and calories to the Late Archaic diet than did molluscs (Morse, 1967; Parmalee \& Klippel, 1974; Dye, 1977). Molluscs, however, provided an important source of vitamin C, niacin, iron and potassium (Watt \& Merrill, 1963; Parmalee \& Klippel, 1974), and as Morse (1967) suggests, they probably served as an important short-term staple when other sources of food failed.

In the 3000 years that elapsed between the Late Archaic and Mississippian periods, the major change in diet was the growth of an agricultural regime which displaced the breadth of the Late Archaic subsistence system. Corn, beans and squash became the dominant vegetable foods, although nuts and wild plants retained an important place in the diet (Griffin, 1967; Ford, 1974, 1977). The exploitation of animal species retained essentially the same order of importance between the two periods, and deer held their pre-eminent position in the diet (Smith, 1975, 1978). Molluscs, however, seem not to have been utilized by Mississippian populations in the Tennessee Valley, although they continued to be locally abundant. In brief, between these two periods, the proportion of plant to animal foods shifted even more in favour of plants, and molluscs were eliminated from the subsistence system. The former change should increase the level of strontium in bone mineral, the latter should decrease the level of strontium markedly.

Beyond the conceptual and empirical problems noted thus far, one of the major limitations in the analysis of strontium in bone is the lack of any recognized standards with a bone-like matrix, such as those available from the National Bureau of Standards for trace elements in other kinds of biological samples (e.g. NBS Bovine Liver SRM1577). In the absence of such standards, the unknown samples should be analysed by two independent methods and the results compared (Morrison, 1976). Such comparison provides a check on random errors that may result from the interaction of a specific method with the matrix of the sample. The check is necessary because when the matrix of the standard differs from the sample matrix the two react differently to any given analytical technique (see Szpunar, 1977, pp. 59-67). The samples from $\mathrm{Lu}^{\circ} 25$ were analysed by both atomic absorption spectrometry and neutron activation analysis. The second technique was considered doubly important in light of Helsby's (1974) demonstration that strontium values were depressed in the analysis of teeth by atomic absorption spectrometry, even when precautions were taken against ionization and interference.

The sample for analysis by atomic absorption spectrometry was a weighed portion of bone (c. $500 \mathrm{mg}$ after drying to a constant weight) which was disolved in $3 \mathrm{ml}$ of concentrated $\mathrm{HCl}$. An aliquot $(0 \cdot 2 \mathrm{ml})$ of the completely dissolved bone was diluted 
$20: 1 \mathrm{in} 3.8 \mathrm{ml}$ of $10 \%$ trichloracetic acid which contained $1 \% \mathrm{La}$ and $0.5 \% \mathrm{~K}$. The prepared sample was analysed by a Varian Techtron with a nitrous oxide acetylene flame. The wavelength was set at $460.8 \mathrm{~nm}$, the lamp current at $10 \mathrm{~mA}$, and the slit width at $0.5 \AA$. The percent absorbance was compared to that of prepared standards.

The sample for neutron activation analysis was bone that had been dried to a constant weight, ground in an agate mortar, and then ashed at $600^{\circ} \mathrm{C}$. Approximately $50 \mathrm{mg}$ of each sample was heat-sealed in suprasil quartz tubing, which had been sterilized by boiling for several hours in aqua regia. The samples, a blank, and two standards were irradiated in the reactor pool for 30 hours. Three weeks after removal from the pool each sample was counted for two hours. The radionuclide that was used to measure strontium concentration was strontium $-85\left(T_{\frac{1}{2}}=62.5\right.$ days $)$ which emits gamma rays of $514 \mathrm{keV}$.

The results (Table 1) indicate that there was a significant difference in the amount of strontium in the Mississippian and Archaic skeletons as measured by both atomic absorption and neutron activation $(\Lambda \mathrm{A}, t=7 \cdot 28 \mathrm{df}=4,0.01>P>0.001$; NAA, $t=4 \cdot 81$, $\mathrm{df}=4,0.01>P>0.001$ ). The similarity of results produced by the two techniques (Mississippian NAA $v$. AAS, $t=1 \cdot 52, \mathrm{df}=4,0.4>P>0.2$; Archaic NAA $v$. AAS, $t=0 \cdot 24$, df $=4,0.9>P>0.5$ ), indicates that the observed levels are valid and not the result of technique error.

Diagenesis does not appear to be a likely explanation for the observed differences for several reasons. First, Parker \& Toots (1980) found no difference in the strontium content of enamel, dentine and bone of fossil Subhyracodon. If post-mortem chemical changes had occurred, the denser enamel should have had a different composition than the other two materials since it would be less subject to chemical alteration. Second, Wyckoff \& Doberenz (1968) compared strontium content in animal bone from the sites of early humans in the western United States, pleistocene animals from California and Arizona, Tertiary animals from Arizona, and even older fossils from all over the world. Where possible the bone strontium levels in these animals were compared to the bone strontium levels in their modern dietary analogues. There was no significant difference in bone strontium levels between the time periods, although there were significant differences in these levels in animals from different geographical areas and between animals ingesting different diets. Third, Nelson (1967) investigated the possibilities of solution and redeposition of strontium in prehistoric clam shells from shell mounds on the Clinch and Tennessee rivers. These shell mounds are temporally and geographically close to the mound from which we took samples. Nelson concluded that no diagenesis had occurred because a heterogeneous distribution of strontium among annual layers was preserved. If measurable solution and redeposition had occurred, this heterogeneity would have been obliterated. In reference to the human skeletons, if diagenesis had occurred and the element followed concentration gradients, the movement of strontium should have been out of the bone. Nelson reports levels of strontium in midden clam shells that are lower than the levels we found in bone, therefore, if solution and redeposition had occurred, the expected result would be a lowering of the amount of strontium in the Archaic skeletons toward equilibrium with the clam shell.

Eliminating technique error and diagenesis as probable explanations, the difference in bone strontium levels is probably due to a dietary shift from the earlier to the later time period. This explanation is in agreement with the remainder of the archaeological record. The change in the level of strontium, however, is not in the direction that would have been predicted: the agriculturalists have much less strontium in their bones than the hunter-gatherers. We believe that the inclusion of molluscs in the diet of the huntinggathering population is the reason for this reversal.

These results suggest that trace element analysis of human bone, especially the analysis 
for strontium, if it is to yield measures of dietary composition, must be carried out in conjunction with some prior knowledge of the range of plants and animals consumed by the population. If organisms such as molluscs that concentrate strontium are included in the diet of one group but not another, then, although these groups might occupy broadly similar positions in the food chain, the strontium analysis would assign them to different trophic levels. In the case discussed here, the Archaic hunter-gatherers would be classified as far more "herbivorous" than the Mississippian agricultural population. In addition, until standards are developed for the trace element composition of human bone, two different techniques of trace element analysis should be employed-one serving as the standard and check for the other.

\section{References}

Asch, N. B., Ford, R. I. \& Asch, D. L. (1972). Paleoethnobotany of the Koster Site: the Archaic horizons. Illinois State Museum Reports of Investigations 24.

Balikci, A. (1968). The Netsilik eskimos: adaptive processes. In (R. B. Lee \& I. DeVore, Eds.). Man the Hunter. Chicago: Aldine Publ. Co., pp. 78-82.

Berg, A. (1972). Metabolism of strontium and calcium in freshwater fish, IV: calcium and strontium relations in fishes of two northern Italian lakes and their general radioecological implications. Memoire dell' Instituto Italiano di Idrobiologica Dott. Marco de Marchi 29, 145-167.

Bowen, H. J. M. \& Dymond, J. A. (1955). Strontium and barium in soils and plants. Proceedings of the Royal Society (London) Series B 144: 355-368.

Brown, A. B. (1973). Bone strontium as a dietary indicator in human skeletal populations. Ph.D. dissertation, University of Michigan, University Microfilms, Ann Arbor, Michigan.

Comar, C. L., Russell, R. S. \& Wasserman, R. H. (1957). Strontium-calcium movement from soil to man. Science 126, 485-492.

Comar, C. L. \& Wasserman, R. H. (1964). Strontium. In (C. L. Comar \& F. Bronner, Eds.) Mineral Metabolism, Vol. 2, Pt. A. New York: Academic Press, pp. 523-572.

Damas, D. (1972). The Copper eskimo. In (M. G. Bicchieri, Ed.) Hunters and Gatherers Today. New York: Holt, Rinehart \& Winston, pp. 3-50.

Dye, D. H. (1977). A model for Late Archaic subsistence systems in the western Middle Tennessee Valley during the Bluff Creek Phase. Tennessee Anthropologist 2, 63-80.

Ford, R. I. (1974). Northeastern archaeology: past and future directions. Annual Review of Anthropology 3, 385-413.

Ford, R. I. (1977). Evolutionary ecology and the evolution of human ecosystems: a case-study from the Midwestern USA. In (J. N. Hill, Ed.) Explanation of Prehistoric Change. Albuquerque: University of New Mexico Press, pp. 153-184.

Gilbert, R. I. (1975). Trace element analyses of three skeletal Amerindian populations at Dickson Mounds. Ph.D. dissertation, University of Massachusetts, University Microfilms, Ann Arbor, Michigan.

Griffin, J. B. (1967). Eastern North American archaeology: a summary. Science 156, 175-191.

Helsby, C. A. (1974). Determination of strontium in human tooth enamel by atomic absorption spectrometry. Analytica Chimica Acta 69, 259-265.

Kulebakina, L. G. (1975). Strontium-90 in the cystoseiric biocenosis of the Black Sea shelf zone. In (A. V. Topachevskii, Ed.) Self-Purification, Bioproductivity and Protection of Reservoirs and Currents of Water in the Ukraine. Kiev, USSR: Naukova Dumka, pp. 102-104.

Lee, R. B. \& DeVore, I. (Eds.) (1968). Man the Hunter. Chicago: Aldine Publ. Co.

Marquardt, W. \& Watson, P. J. (n.d.). Excavation and recovery of biological remains from two Archaic shell middens in western Kentucky. Southeastern Archaeological Conference Bulletin (in press).

Marchall, J. H., Liniecki, J., Lloyd, E. L., Marotti, G., Mays, C. W., Rundo, J., Sissons, H. A. \& Snyder, W. S. (1973). Alkaline earth metabolism in adult man. Health Physics 24, 125-221. 
McLean, F. C. \& Urist, M. R. (1968). Bone: An Introduction to the Physiology of Skeletal Tissue 3rd Edn. Chicago: University of Chicago Press.

Morrison, G. H. (1976). Interpretation of accuracy of trace element results for biological materials. National Bureau of Standards Special Publications 422, 65-78.

Morrison, J. E. P. (1942). Preliminary report on molluscs found in the shell mounds of the Pickwick Landing Basin in the Tennessee River Valley. Smithsonian Institution, Bureau of American Ethnology, Bulletin 129, 337-392.

Morse, D. F. (1967). The Robinson site and shell mound archaic cultures of the Middle South. Ph.D. dissertation, University of Michigan, University Microfilms, Ann Arbor, Michigan.

Nelson, D. J. (1967). Microchemical constituents in contemporary and Pre-Columbian clamshell. In (E. J. Cushing \& H. E. Wright, Jr., Eds.) Quarternary Paleoecology. New Haven: Yale University Press, pp. 185-204.

Neuman, W. F., Bjornerstedt, R. \& Mulryan, B. J. (1963). Synthetic hydroxyapatite crystals, II. Ageing and strontium incorporation. Archives of Biochemistry and Biophysics 101, 215-224.

Odum, E. P. (1971). Fundamentals of Ecology 3rd Edn. Philadelphia: W. B. Saunders.

Odum, H. T. (1951). The stability of the world strontium cycle. Science 114, 407-411.

Ophel, I. L. (1963). The fate of radiostrontium in a freshwater community. In (V. Schultz \& A. W. Klement, Eds.) Radioecology. London: Chapman and Hall, pp. 213-216.

Parker, R. B. \& Toots, H. (1980). Trace elements in bones as paleobiological indicators. In (A. K. Behrens-meyer \& A. P. Hill, Eds.) Fossils in the Making. Chicago: University of Chicago Press, pp. 197-207.

Parmalee, P. W. \& Klippel, W. E. (1974). Freshwater mussels as a prehistoric food resource. American Antiquity 39, 421-434.

Reeve, J. \& Hesp, R. (1976). A model-independent comparison of the rates of uptake and short-term retention of calcium- 47 and strontium- 85 by the skeleton. Journal of Calcified Tissue Research 22, 183-189.

Schoeninger, M. J. (1979a). Dietary reconstruction at Chalcatzingo, a Formative Period site in Morelos, Mexico. Museum of Anthropology, University of Michigan, Technical Reports 9.

Schoeninger, M. J. (1979b). Diet and status at Chalcatzingo: some empirical and technical aspects of strontium analysis. American Journal of Physical Anthropology (in press).

Schroeder, H. A., Tipton, I. H. \& Nason, A. P. (1972). Trace metals in man: strontium and barium. Journal of Chronic Diseases 25, 491-517.

Smith, B. D. (1975). Middle Mississippi exploitation of animal populations. Anthropological Papers, Museum of Anthropology, University of Michigan 57.

Smith, B. D. (1978). Variation in Mississippian settlement patterns. In (B. D. Smith, Ed.) Mississippian Settlement Patterns. New York: Academic Press, pp. 479-503.

Szpunar, C. B. (1977). Atomic absorption analysis of archaeological remains: human ribs from Woodland Mortuary Sites. Ph.D. dissertation, Northwestern University, University Microfilms, Ann Arbor, Michigan.

Toots, H. \& Voorhies, M. R. (1965). Strontium in fossil bones and reconstruction of food chains. Science 149, 854-855.

Underwood, E. J. (1977). Trace Elements in Human and Animal Nutrition. New York: Academic Press.

Vose, P. B. \& Koontz, H. V. (1955). The uptake of strontium by pasture plants and its possible significance in relation to the fall-out of strontium-90. Nature 183, 1447-1448.

Watt, B. K. \& Merrill, A. L. (1963). Composition of Foods, Raw, Processed, Prepared. Washington, D.C.: U.S. Government Printing Office.

Webb, W. S. \& DeJarnette, D. L. (1942). An archaeological survey of Pickwick Basin in the adjacent portions of the states of Alabama, Mississippi and Tennessee. Smithsonian Institution, Bureau of American Ethnology, Bulletin 129.

Webb, W. S. \& DeJarnette, D. L. (1948). The Perry Site Lu ${ }^{\circ} 25$, Units 3 and 4, Lauderdale County, Alabama. Alabama Museum of Natural History, Tuscaloosa, Alabama, Museum Paper 25.

Wyckoff, R. W. G. \& Doberenz, A. R. (1968). The strontium content of fossil teeth and bones. Geochimica Cosmochimica Acta 32, 109-115. 